\title{
DAUR ULANG LIMBAH SHAVING INDUSTRI PENYAMAKAN KULIT UNTUK KERTAS SENI
}

\section{(RECYCLING OF SHAVING WASTE FROM TANNING INDUSTRY FOR ART PAPER)}

\author{
Sri Sutyasmi \\ Balai Besar Kulit, Karet dan Plastik, Yogyakarta \\ Email: srisutyasmi@ymail.com \\ Diterima: 11 September 2012 Revisi: 5 Nopember 2012 Disetujui: 4 Desember 2012
}

\begin{abstract}
A research has been done on recycling of shavings waste for art paper. The aim of this research was to utilize shaving waste from tanning industry for making art paper in order not to pollute the environment, and to add raw materials to the manufacture of art paper. In this study the majority of shaving waste was used as a motif $(20 \%)$ and partly made of pulp (10\%) together with paper waste (newspaper). As the materials starch and resin adhesive (fox) used was (1\%) that served as an adhesive. Dyes were used to the beauty of the appearance of art paper. There were two stages of the paper making, first made from waste paper pulp added with the waste shaving, then printing given motives shaving motive of waste too. Part of the sheet of paper were pressed (about half), and the other parts were not pressed. They were then tested on gramatur art paper, tear index, tensile index, and the fracture index. The test results showed that pressed art paper had a tear index, tensile index and the fracture index $\left(3.85 ; 0.59 ; 8.4 \times 10^{-3}\right)$, and the impressed was $\left(3.57 ; 0.52 ; 6.9 \times 10^{-3}\right)$ respectively the art paper that used fox adhesive on the pressed $(15,545$; 0,$\left.76 ; 3528 \times 10^{-1}\right)$, and on impressed $\left(16,366 ; 0,80 ; 3549 \times 10^{-1)}\right.$. The overall appearance of art paper results could still compete with the art of paper are the market.
\end{abstract}

Keywords: shaving waste, recycling, pollution, art paper

\begin{abstract}
ABSTRAK
Telah dilakukan penelitian daur ulang limbah shaving untuk kertas seni. Tujuan dari penelitian ini adalah untuk mendaur ulang limbah shaving industri penyamakan kulit untuk dibuat kertas seni agar tidak mencemari lingkungan dan menambah bahan baku pembuatan kertas seni. Dalam penelitian ini limbah shaving sebagian digunakan sebagai motif (20\%) dan sebagian lagi dibuat pulp (10\%) bersama-sama dengan kertas bekas (koran). Sebagai bahan pembantu digunakan pati kanji dan juga lem fox (1\%) yang berfungsi sebagai perekat. Pewarna digunakan untuk memperindah penampilan kertas seni. Ada dua tahap pembuatan kertas seni ini yaitu pertama membuat pulp dari kertas bekas yang ditambah dengan limbah shaving, kemudian pencetakan yang diberi motif limbah shaving pula. Lembaran kertas seni yang dihasilkan ada yang di pres (sekitar setengahnya) dan sisanya tidak dipres. Kertas seni kemudian diuji gramatur, indeks sobek, indeks retak dan indeks tarik. Hasil uji kertas seni yang menggunakan lem pati kanji menunjukkan bahwa kertas seni yang dipres mempunyai indeks sobek, indeks retak dan indeks tarik $\left(3,85 ; 0,59 ; 8,4 \times 10^{-3}\right)$ dan yang tidak di pres $\left(3,57 ; 0,52 ; 6,9 \times 10^{-3}\right)$, sedangkan kertas seni yang menggunakan lem fox dan di press mempunyai indeks sobek, indeks retak dan indeks tarik $\left(15,545 ; 0,76 ; 3528 \times 10^{-1}\right)$ yang tidak di press $\left(16,366 ; 0,80 ; 3549 \times 10^{-1)}\right.$. Secara keseluruhan penampilan kertas seni hasil penelitian masih bisa bersaing dengan kertas seni yang ada di pasaran.
\end{abstract}

Kata kunci: limbah shaving,daur ulang, pencemaran, kertas seni 


\section{PENDAHULUAN}

Dalam rangka ikut serta melestarikan lingkungan maka industri penyamakan kulit yang sudah terkenal potensial mencemari lingkungan harus bisa menangani atau mengolah limbah yang dihasilkan agar industri tetap bisa beroperasi.

Limbah shaving adalah limbah padat dari kulit tersamak yang berupa serutan kulit. Volume limbah shaving industri penyamakan kulit ini sangat besar, Limbah tersebut mempunyai sifat ringan, tidak mudah terdegradasi, tidak mudah rusak oleh bahan kimia, mikroorganisme, bahkan oleh perlakuan fisik.

Potensi kulit sapi dan kerbau seluruh indonesia yang menghasilkan limbah shaving adalah sebagai berikut; Jabotabek : 35,40 juta kaki persegi atau sekitar 17,7 juta $\mathrm{kg}$, Jawa Barat : 15,70 juta kaki persegi atau sekitar 7,85 juta kg, Jawa Tengah : 7,60 juta kaki persegi atau sekitar 3,80 kg, Yogyakarta : 1,70 juta kaki persegi atau sekitar 0,85 juta $\mathrm{kg}$, Jawa Timur : 54,50 juta kaki persegi atau sekitar $27,25 \mathrm{~kg}$. Dengan demikian potensi kulit sapi dan kerbau yang menghasilkan limbah shaving di pulau Jawa saja sekitar 57,45 juta kaki persegi atau 28,275 juta $\mathrm{kg}=28.275 .000$ ton (Sunaryo, 2002). Limbah padat ini umumnya masih mengandung krom untuk kulit yang disamak krom dan formalin untuk kulit yang disamak formaldehid. Volume limbah shaving ini berkisar antara $99 \mathrm{~kg}$ untuk setiap ton kulit yang diproses (Zhiwen, D., 2008), sehingga limbah shaving yang dihasilkan khusus dari hasil penyamakan kulit sapi dan kerbau di pulau Jawa saja $=2.799 .225$ ton.

Limbah shaving sebetulnya merupakan kumpulan serat protein kolagen yang sangat halus dengan sifat yang tidak mudah rusak oleh mikroorganisme, bahan kimia bahkan perlakuan fisik (Sri-Sutyasmi, 2009). Adapun struktur jaringan kolagen kulit tersamak krom adalah sebagai berikut.

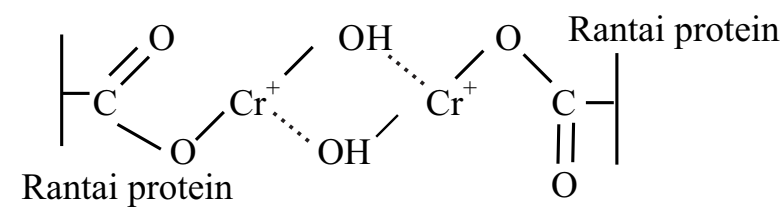

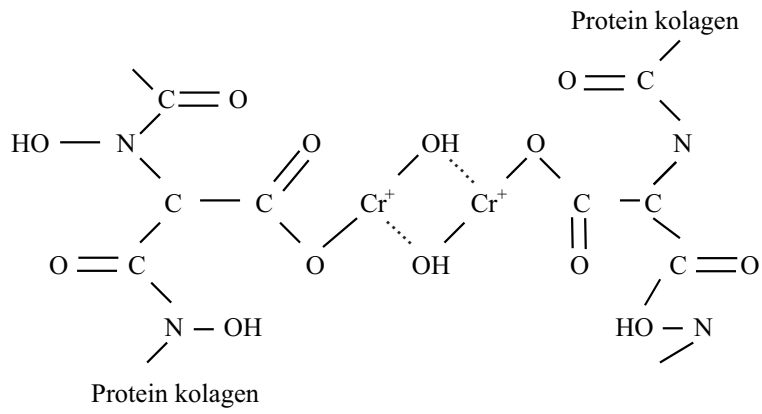

Gambar 1. Struktur jaringan kolagen kulit tersamak krom (Anonim, 2008)

Jadi dapat kita ketahui bahwa kulit wetblue tersebut bermuatan positif, selain dari unsur kromnya juga rantai ujung amina atau rantai samping yang pada suasana $\mathrm{pH}$ rendah akan terdisosiasi menjadi $-\mathrm{NH}_{3}{ }^{+}$. Muatan ini akan reaktif dengan semua molekul yang bermuatan negatif (-) pada bahan pembantu seperti resin atau pewarna.

Sifat-sifat itulah yang dijadikan acuan untuk memanfaatkan limbah shaving menjadi kertas karena merupakan solusi untuk masalah kekurangan bahan baku pulp yang sekaligus mengurangi dampak polusi dari industri penyamakan kulit. Alternatif ini menguntungkan semua pihak baik industri penyamakan kulit maupun industri kertas mengingat bahan tersebut merupakan buangan yang tidak mempunyai nilai namun bisa bermanfaat.

Salah satu bentuk pemanfaatan yang mudah dilaksanakan dan murah biayanya ialah menggunakannya untuk bahan pembuatan kertas seni. Kertas seni (art paper) merupakan salah satu jenis produk kertas yang akhir-akhir ini semakin banyak diminati baik oleh pasar di dalam negeri maupun luar negeri. Pada umumnya jenis kertas seni merupakan hasil buatan tangan dengan bentuk desain yang unik dan menarik. Bahan baku yang digunakan sangat bervariasi mulai dari kertas bekas sampai dengan pulp yang dibuat dari limbah pertanian seperti merang, jerami, dan lain sebagainya.

Selulosa adalah polisakarida yang terdiri dari rantai linear dari beberapa ratus hingga lebih dari sepuluh ribu ikatan $\beta(1 \rightarrow 4)$ unit D-glukosa. Selulosa adalah karbohidrat utama yang disintesis oleh tanaman dan menempati hampir $60 \%$ komponen penyusun 
struktur kayu. Selulosa merupakan serat-serat panjang yang bersama-sama hemiselulosa, pektin, dan protein membentuk struktur jaringan yang memperkuat dinding sel tanaman (Tahirzadeh, et al., 2008). Jumlah selulosa di alam sangat berlimpah sebagai sisa tanaman atau dalam bentuk sisa pertanian seperti jerami padi, kulit jagung, gandum,kulit tebu dan lain-lain tumbuhan.

Salah satu kesamaan sifat limbah shaving dan kertas adalah sama-sama mudah menyerap air. Peresapan air ke dalam suatu benda akan mengisi (berikatan) secara kimiawi melalui ikatan hidrogen. Terbentuknya ikatan hidrogen antara molekul air dengan serat/molekul lain dikarenakan polaritas molekul tersebut (Marcot, 2007), dalam hal ini serat kulit atau serat protein yang telah disamak. Mekanisme tersebut sama dengan yang terjadi pada serat selulosa. Kepolaran suatu molekul ditentukan juga oleh susunan atom yang terdapat pada molekul serat, hanya pada umumnya atom-atom tertentu saja seperti $\mathrm{C}, \mathrm{H}, \mathrm{N}$, dan $\mathrm{O}$, pada hal rantai protein tersusun dari asam amino yang terdiri dari atom $\mathrm{C}, \mathrm{H}, \mathrm{N}$ dan $\mathrm{O}$. Hal ini pula yang menyebabkan serat kulit bisa menggantikan serat selulosa.

Untuk membuat kertas seni terlebih dahulu dibuat pulp, kemudian untuk membuat corak atau motif pada kertas seni tersebut dapat menggunakan berbagai bahan seperti daun suji, daun pandan, daun bawang, serat pelepah pisang, serat nanas dan lain sebagainya, yang dalam penelitian ini limbah shaving disamping digunakan untuk campuran pembuatan bubur kertas juga bisa digunakan untuk corak.

\section{Proses pembuatan kertas daur ulang} (Alamsyah, 2011).

- Pertama, tentukan warna dan tekstur kertas daur ulang yang ingin dihasilkan. Jika menginginkan hasil kertas daur ulang yang bersih, putih dan halus maka gunakan kertas berjenis HVS. Jika menginginkan hasil kertas daur ulang yang berwarna gelap kecoklatan, tekstur agak kasar gunakan kertas koran.

- Kedua, kelompokkan kertas sesuai jenisnya lalu potong kecil-kecil dan rendam semalaman agar mudah saat di blender/dihancurkan (pembuatan bubur kertas). Saat memblender tambahkan air jika dibutuhkan, komposisi jumlah air yang diperlukan tidak ada patokan pasti. Yang penting kertas bisa hancur menjadi bubur namun tidak encer.

- Ketiga, campurkan bubur kertas kedalam wadah cetakan yang sudah diberi campuran air dan lem. Saat inilah kita bisa menambahkan warna dan bahan campuran lainnya seperti dedaunan, pelepah pisang, bunga kering dan sebagainya sesuai keinginan dan kreativitas.

- Keempat, aduk adonan bubur kertas hingga benar-benar rata lalu masukkan screen cetakan (screen sablon), angkat dan biarkan airnya menetes. Setelah itu pindahkan ke alas cetak dan keringkan. Proses pengeringan sebaiknya tidak dilakukan dibawah terik matahari langsung melainkan cukup diangin-anginkan saja agar kertas daur ulang yang dihasilkan tetap rata dan tidak menggulung.

- Kelima, kertas daur ulang siap diolah menjadi produk lain.

Tujuan dari penelitian ini adalah mendaur ulang limbah shaving industri penyamakan kulit untuk dibuat kertas seni agar tidak mencemari lingkungan dan menambah bahan baku kertas seni.

\section{BAHAN DAN METODE PENELITIAN}

\section{Bahan dan Metode}

Bahan yang digunakan dalam penelitian ini ialah limbah shaving dari industri penyamakan kulit, koran bekas, pati kanji, lem fox dan pewarna.

Alat yang digunakan dalam penelitian ini semula adalah blender sebagai alat penghancur atau untuk pembuatan pulp (bubur kertas), cetakan dari kasa dengan ukuran lobang 150 -200 mesh, ember besar untuk tempat pulp dan penyaringan pulp serta papan/triplek yang dilapisi dengan kain penyerap. Namun dalam perkembangannya alat yang digunakan dalam membuat kertas seni tersebut adalah dirancang menjadi satu set alat untuk membuat pulp maupun untuk mencetak kertas seni seperti gambar berikut ini. Alat tersebut terdiri dari penampungan air, 
bitter (penghancur) untuk pembuatan pulp dan penyaring untuk mencetak kertas seni dengan ukuran kertas double folio dan ukuran lobang $150-200$ mesh.

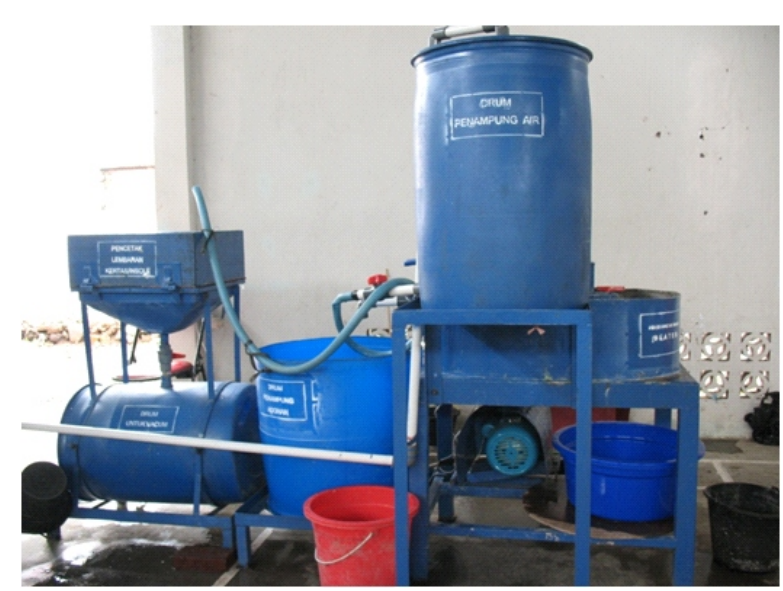

Gambar 1: Alat untuk membuat kertas seni

\section{Metode}

Lingkup dari proses pembuatan kertas seni ini terdiri dari 2 tahap yaitu pertama tahap pembuatan pulp dan kedua adalah pencetakan kertas seni.

Pada tahap pembuatan pulp kertas koran bekas dan limbah shaving masing-masing ditimbang sesuai kebutuhan untuk pembuatan kertas seni. Setiap lebar kertas seni beratnya sekitar 15 gram yaitu $68 \%$ koran (10,2 gram ), $10 \%$ limbah shaving ( 1,5 gram) dan 20\% (3 gram) limbah shaving untuk motif. Selanjutnya koran bekas dan limbah shaving dibuat pulp menggunakan blender atau dalam bitter (penghancur) dengan konsistensi 1,5\% (1,5 gram bahan serat kering dalam 98,5 ml air) dan ditambah pewarna secukupnya ( $1 \%$ ) dan pati kanji sebesar $1 \%$. Untuk pengembangannya digunakan lem fox. Waktu yang diperlukan untuk proses penghancuran ini adalah 5 menit. Setelah bahan menjadi pulp (bubur kertas), selanjutnya pulp masuk tahap kedua yaitu pencetakan kertas seni. Pulp kemudian dimasukkan di atas cetakan kasa dengan ukuran lubang 150-200 mesh sambil diaduk agar merata, bila perlu tambahkan lagi air untuk memudahkan pengadukan. Pulp ditiriskan di atas kasa dengan menggunakan papan/tripllek yang dilapisi dengan kain penyerap. Untuk penggunaan limbah shaving sebagai motif, ditaburkan limbah shaving sebesar $20 \%$ (3 gram) pada permukaan lembaran, dilakukan penirisan sebagian air sampai kira-kira air setinggi $1 \mathrm{~cm}$ diatas kasa, kemudian diatur motif sesuai keinginan dan air yang tersisa ditiriskan.

Untuk mendapatkan lembaran dengan berat yang diinginkan, maka banyaknya pulp yang diambil dapat dihitung dengan cara sebagai berikut :

$$
\mathrm{V}=\frac{100 \mathrm{p} \cdot 1 . \mathrm{g}}{\mathrm{C}}
$$

Jika :

$$
\begin{aligned}
\mathrm{V} & =\text { volume pulp }(\mathrm{ml}) \\
\mathrm{g} & =\text { berat lembaran }\left(\mathrm{gm}^{2}\right) \\
\mathrm{p} & =\text { panjang lembaran }(\mathrm{m}) \\
\mathrm{l} & =\text { lebar lembaran }(\mathrm{m}) \\
\mathrm{C} & =\text { konsistensi pulp }(\%)
\end{aligned}
$$

Lembaran kertas yang masih basah kemudian diangkat dan dikeringkan dibawah sinar matahari atau diangin-anginkan. Setelah kering agar permukaan rata kertas seni dipres, namun ada juga yang tidak dipres. Kertas seni kemudian diuji gramatur, indeks sobek, indeks retak dan indeks tarik baik yang dipres maupun yang tidak. Berikut ini adalah diagram alir proses pembuatan kertas seni.

Apabila menggunakan alat tersebut diatas maka bekerjanya alat tersebut adalah sebagai berikut! limbah shaving dan kertas bekas dimasukkan dalam bitter (penghancur), selanjutnya pulp (bubur) dialirkan ke saringan, demikian juga air sampai dengan $2 / 3$ bagian dari kotak saringan, kemudian setelah air tinggal 1/3 dimasukkan motif dan air ditiriskan melalui pegas pembuangan sampai air kering, selanjutnya kotak saringan diangkat/dibuka dan diatas saringan diberi kain penyerap serta triplek, kemudian ditekan agar adonan menempel pada kain penyerap dan triplek untuk selanjutnya dijemur atau di angin-anginkan. Apabila matahari panasnya penuh maka waktu penjemuran selama 2-3 jam dan apabila tidak ada panas matahari/agak mendung maka waktu penjemuran bisa sampai setengah hari. 


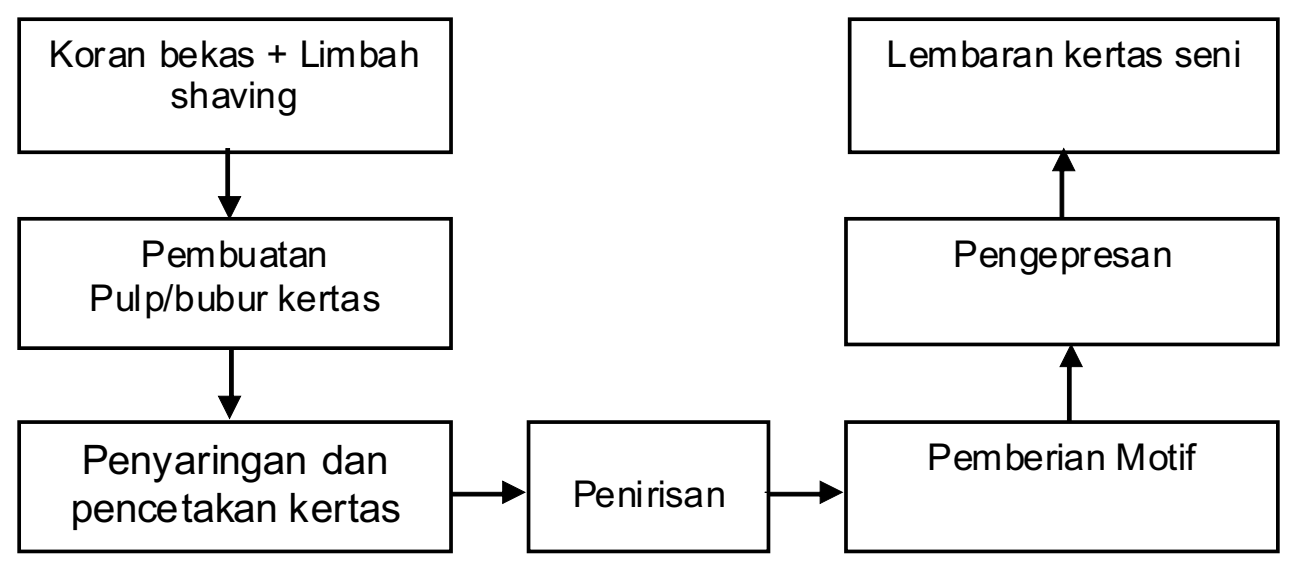

Gambar 2. Diagram Alir Proses Pembuatan Kertas Seni

\section{HASILDAN PEMBAHASAN}

\section{Hasil Penelitian}

\section{Hasil Uji limbah Shaving}

Untuk mengetahui kandungan yang terdapat dalam limbah shaving maka limbah shaving perlu diuji kandungan bahan kimianya. Adapun hasil uji limbah shaving tersebut dapat dilihat pada Tabel 1.

Tabel 1. Hasil uji limbah shaving dari industri penyamakan kulit

\begin{tabular}{|l|l|c|}
\hline No. & Komponen & Jumlah (\%) \\
\hline 1 & Kadar air & 37,82 \\
\hline 2 & Kadar N Total & 9,25 \\
\hline 3 & Kadar protein & 52,45 \\
\hline 4 & Kadar Krom & 3,74 \\
\hline 5 & Kadar lemak & 0,58 \\
\hline
\end{tabular}

Dari hasil uji bahan dasar (limbah shaving) di atas dapat diketahui bahwa kandungan terbesar pada limbah shaving adalah kadar protein, berikutnya kadar air, dan selanjutnya berturut-turut kadar $\mathrm{N}$ total dan kadar $\mathrm{Cr}_{2} \mathrm{O}_{3}$ dan yang paling rendah adalah kadar lemak. Adanya kadar lemak yang rendah tersebut memungkinkan serat kulit untuk bersatu dengan serat selulosa dari kertas bekas, sedangkan unsur-unsur yang lain seperti, $\mathrm{N}$ total dan protein sangat mendukung tersedianya atom-atom seperti $\mathrm{C}, \mathrm{H}, \mathrm{N}$, dan $\mathrm{O}$.
Atom-atom tersebut merupakan faktor yang menentukan kepolaran suatu molekul yang ditentukan oleh susunan atom yang terdapat pada molekul serat. Terbentuknya ikatan hidrogen antara molekul air dengan serat/molekul lain dikarenakan polaritas molekul tersebut (Marcot, 2007) dalam hal ini serat kulit atau serat protein yang telah disamak. Mekanisme tersebut sama dengan yang terjadi pada serat selulosa, hanya pada umumnya atom-atom tertentu saja seperti C, $\mathrm{H}, \mathrm{N}$, dan $\mathrm{O}$, pada hal rantai protein tersusun dari asam amino yang terdiri dari atom $\mathrm{C}, \mathrm{H}, \mathrm{N}$ dan $\mathrm{O}$. Hal ini pula yang menyebabkan serat kulit bisa menggantikan serat selulosa.

Untuk dapat mengetahui kertas seni yang dibuat dari limbah shaving dapat dilihat pada gambar berikut ini.

\section{Hasil uji Kertas Seni}

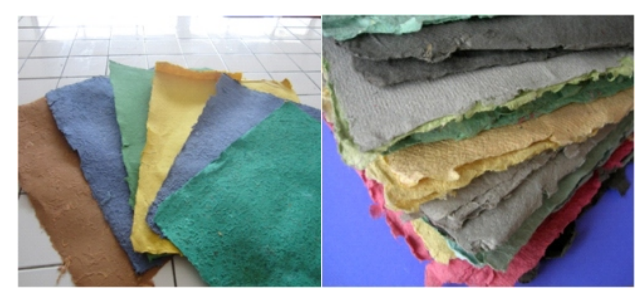

Gambar 3. kertas daur ulang hasil penelitian

Dilihat dari kenampakan kertas seni hasil penelitian tidak berbeda jauh dengan kertas seni yang ada di pasaran. Hasil uji kertas seni dari limbah shaving hasil penelitian yang menggunakan lem pati kanji dan pembandingnya dapat dilihat pada Tabel 2 . 
Tabel 2. Hasil uji kertas seni dengan lem pati kanji

\begin{tabular}{|c|c|c|c|c|}
\hline \multirow[t]{2}{*}{ Parameter } & \multirow[t]{2}{*}{ Satuan } & \multicolumn{2}{|c|}{ Kertas Seni Hasil Penelitian } & Kertas Seni \\
\hline & & $\begin{array}{l}\text { Kertas Seni } \\
\text { Tidak dipres }\end{array}$ & $\begin{array}{l}\text { Kertas Seni } \\
\text { Dipres }\end{array}$ & $\begin{array}{l}\text { Sebagai } \\
\text { Pembanding }\end{array}$ \\
\hline Gramatur & $\mathrm{Gr} / \mathrm{m}^{2}$ & 133,67 & 126,38 & 125,12 \\
\hline Indeks sobek & $\mathrm{m} \mathrm{Nm}^{2} / \mathrm{gr}$ & 3,57 & 3,85 & 3,80 \\
\hline Indeks retak & $\mathrm{k} \mathrm{Pa} \mathrm{m}^{2} / \mathrm{gr}$ & 0,22 & 0,31 & 0.60 \\
\hline Indeks tarik & $\mathrm{k} \mathrm{Nm} / \mathrm{gr}$ & $3,9 \times 10^{-3}$ & $4,4 \times 10^{-3}$ & $10 \times 10^{-3}$ \\
\hline
\end{tabular}

Dari Tabel 2. di atas dapat diketahui bahwa secara keseluruhan penampilan dari kertas seni dari limbah shaving hasil penelitian sedikit berbeda dengan kertas seni yang diperoleh di dipasaran. Kertas seni hasil penelitian mempunyai indek sobek yang hampir sama dengan kertas seni yang ada dipasaran. Namun demikian untuk indeks retak dan indeks tarik masih dibawah kertas seni pembanding.

Hasil uji indeks retak dan indeks tarik yang masih dibawah hasil uji kertas pembanding kemungkinan disebabkan karena kertas daur ulang yang digunakan untuk campuran pulp adalah koran bekas yang mempunyai serat pendek (Ngatijo, 1995). Disamping itu lem/perekat yang digunakan hanyalah pati yang tentu saja tidak bisa merekat dengan baik dengan serat kulit. Untuk membuktikan dugaan penggunaan lem yang kurang tepat maka dicoba untuk penggunaan lem fox sebagai perekat untuk menggantikan lem pati kanji. Hasil uji kertas seni yang menggunakan lem fox terlihat pada Tabel 3.

Tabel 3. Hasil Uji kertas seni dengan menggunakan lem fox

\begin{tabular}{|c|c|c|c|c|}
\hline \multirow[t]{2}{*}{ Parameter } & \multirow[t]{2}{*}{ Satuan } & \multicolumn{2}{|c|}{ Kertas Seni Hasil Penelitian } & Kertas Seni \\
\hline & & $\begin{array}{l}\text { Kertas Seni } \\
\text { Tidak dipres }\end{array}$ & $\begin{array}{l}\text { Kertas Seni } \\
\text { Dipres }\end{array}$ & $\begin{array}{l}\text { Sebagai } \\
\text { Pembanding }\end{array}$ \\
\hline Gramatur & $\mathrm{Gr} / \mathrm{m}^{2}$ & 133,67 & 126,38 & 125,12 \\
\hline Indeks sobek & $\mathrm{m} \mathrm{Nm}^{2} / \mathrm{gr}$ & 3,57 & 3,85 & 3,80 \\
\hline Indeks retak & $\mathrm{k} \mathrm{Pa} \mathrm{m}^{2} / \mathrm{gr}$ & 0,22 & 0,31 & 0.60 \\
\hline Indeks tarik & $\mathrm{k} \mathrm{Nm} / \mathrm{gr}$ & $3,9 \times 10^{-3}$ & $4,4 \times 10^{-3}$ & $10 \times 10^{-3}$ \\
\hline
\end{tabular}

Dari data diatas dapat diketahui bahwa penggantian lem dari lem pati kanji dengan lem fox sangat berpengaruh pada kualitas kertas seni yang terbuat dari limbah shaving yaitu indeks sobek, indeks retak dan indeks tarik. Apabila dibandingkan dengan kertas seni pembanding yang ada di pasaran maka kertas seni dari limbah shaving (kertas seni hasil penelitian) jauh lebih baik kualitasnya dibanding kertas seni yang ada di pasaran, walaupun bahan baku kertas bekas yang
Pasaribu (2007) mengemukakan bahwa pembuatan kertas memerlukan lem sebagai perekat sekitar $5 \%$, sedangkan dalam penelitian ini hanya $1 \%$. Ini membuktikan bahwa pemakaian lem fox sebagai perekat dalam daur ulang limbah shaving untuk pembuatan kertas seni adalah sudah cocok/sesuai. Menurut Aizz (2011) pembuatan kertas daur ulang memerlukan lem pati sekitar 10-15 gram lem untuk setiap $250 \mathrm{~g}$ bahan baku kertas.

Kandungan kimia bahan baku pulp 
untuk kertas seni yang perlu diperhatikan menurut Abhinimpuno (2007) adalah kandungan serat selulosa dan ligninnya. Menurut Harun, et al. (2004), sifat kertas seni yang dibuat secara manual menggunakan tangan yang paling diutamakan adalah nilai seni yang tinggi dan warna yang kas, bukan kekuatan kertas. Namun sifat seperti ini belum mempunyai nilai kualitatif yang pasti karena bersifat penilaian yang beragam tergantung dari sifat penglihatan perorangan.

Untuk indeks retak dan indeks tarik dari kertas seni yang dipres hasilnya lebih baik dibanding dengan kertas seni yang tidak di pres. Hal ini kemungkinan karena serat-serat kulit dan serat selulosa bisa saling berkaitan dengan adanya pengepresan. Sebetulnya untuk kertas seni tidak diperlukan nilai kekuatan tarik, retak maupun sobek yang tinggi, karena lebih diutamakan ke masalah seninya, Hal ini dikarenakan kertas seni biasanya digunakan untuk pelapis atau pembungkus suatu produk sehingga tidak diperlukan kekuatan tarik yang tinggi. Tinggi rendahnya kuat rekat serat tidak terlepas dari faktor jenis, jumlah zat seperti resin atau polimer yang dapat berfungsi sebagai binder antar serat.

Pada proses pembuatan pulp, saat air yang terdapat pada pulp kertas mulai berkurang (pada proses pengeringan), maka resin atau polimer secara bersamaan membentuk satu jaringan di antara serat sehingga dapat menyatukan seluruh serat dan membentuk satu lapisan. Lapisan polimer/resin tersebut menjadi tumpuan rekat serta kekuatan dari kertas secara keseluruhan. Apabila lapisan yang terbentuk sempurna maka akan meningkatkan kekuatan kertas (Anonim, 2011).

Faktor lain yang mempengaruhi kuat rekat adalah seperti dikemukakan oleh EurControl, yaitu penampilan serat kasar atau halus. Serat halus bisa lebih fleksibel, dan bila mendapat tekanan secara axial, bisa menyebabkan kekuatan kertas yang lebih baik. Di samping itu dengan cara memintal serat secara bersama, maka akan membuat batang-batang serat dan struktur kertas menjadi kuat.

Menurut Urip-Santoso (2009), kertas dapat didaur ulang dengan mencampurkan kertas bekas yang telah dijadikan pulp dengan material kertas baru. Namun kertas akan selalu mengalami penurunan kualitas jika terus didaur ulang. Hal ini menjadikan kertas harus didaur ulang dengan mencampurkannya dengan material baru, atau mendaur ulangnya menjadi bahan yang berkualitas lebih rendah. Limbah shaving merupakan material baru yang perlu ditambahkan pada proses daur ulang, sehingga akan mengurangi pencemaran dan menambah bahan baku kertas. Dengan demikian masalah pencemaran lingkungan sudah teratasi, demikian juga masalah bahan baku kertas yang ternyata banyak menebang hutan juga sudah teratasi.

Dilihat dari aspek teknologi dapat diketahui bahwa pembuatan kertas seni dengan memanfaatkan limbah shaving dan kertas bekas (koran) menggunakan teknologi yang sangat sederhana dan mudah untuk bisa dilakukan siapa saja. Terlebih lagi bahan baku yang digunakan merupakan limbah yang banyak tersedia di industri penyamakan kulit dan peralatannyapun amat sangat sederhana. Kendala utama pada proses pembuatan kertas seni dari limbah shaving ini adalah pada penghancuran menjadi pulp, kulit sangat liat karena kulit mempunyai tingkat kemuluran serat cukup tinggi bila dibanding dengan serat selulosa. Dampak dari sifat kulit ini adalah sulit memperoleh besar serat yang homogen, sehingga lapisan kertas kemungkinan tidak cukup rapat walaupun sudah mendapat tekanan mekanis. Dampak lain adalah ketebalan kulit tidak merata karena daerah yang berserat lebih besar kelihatan lebih tebal.

Namun demikian secara keseluruhan dalam proses pembuatan pulp tidak mengalami kesulitan bahkan tidak menggunakan bahan kimia tambahan untuk membantu penghancuran seperti $\mathrm{NaOH}$ dan lain-lain. Dilihat dari aspek ekonomi pembuatan kertas seni dari limbah shaving sangat menguntungkan karena biaya murah, bahan baku mudah dan berlimpah karena semua dari limbah. Dari hasil perhitungan ekonomi yang dihitung dari produksi 50 lembar per hari dapat dilihat pada Tabel 4 . Sedangkan perkiraan penggunaan limbah shaving untuk kertas seni dari industri kulit 
adalah seperti berikut ini.

Perhitungan berikut menggunakan dasar $10 \%$ atau seberat 2.799.225 ton dari jumlah total limbah shaving kulit sapi dan kerbau yang dihasilkan oleh industri penyamakan kulit di Indonesia. Besarnya limbah shaving yang digunakan untuk campuran komponen/adonan pembuatan kertas seni adalah $30 \%$ dari total bahan. Dengan demikian jumlah limbah shaving yang bisa dimanfaatkan untuk pembuatan kertas seni, adalah sebesar 279.922 .500 ton $\times 30 \%=$

\subsection{6 .750 ton.}

Berat kertas seni per lembar adalah 15 gram. Penggunaan limbah shaving per lembar kertas seni adalah $30 \%$ atau sebesar 4,5 gram, sehingga per kilogram limbah shaving dapat dihasilkan lembar kertas seni sebanyak 222 lembar. Bila harga jual per lembar kertas seni Rp 780 maka bila dinilai dengan rupiah, kertas seni sebanyak 222 lembar tersebut di atas mempunyai nilai jual sebesar $\mathrm{Rp}$. 173.160,- atau dibulatkan menjadi Rp. 175.000,-

Tabel 4. Analisa ekonomi industri kertas seni

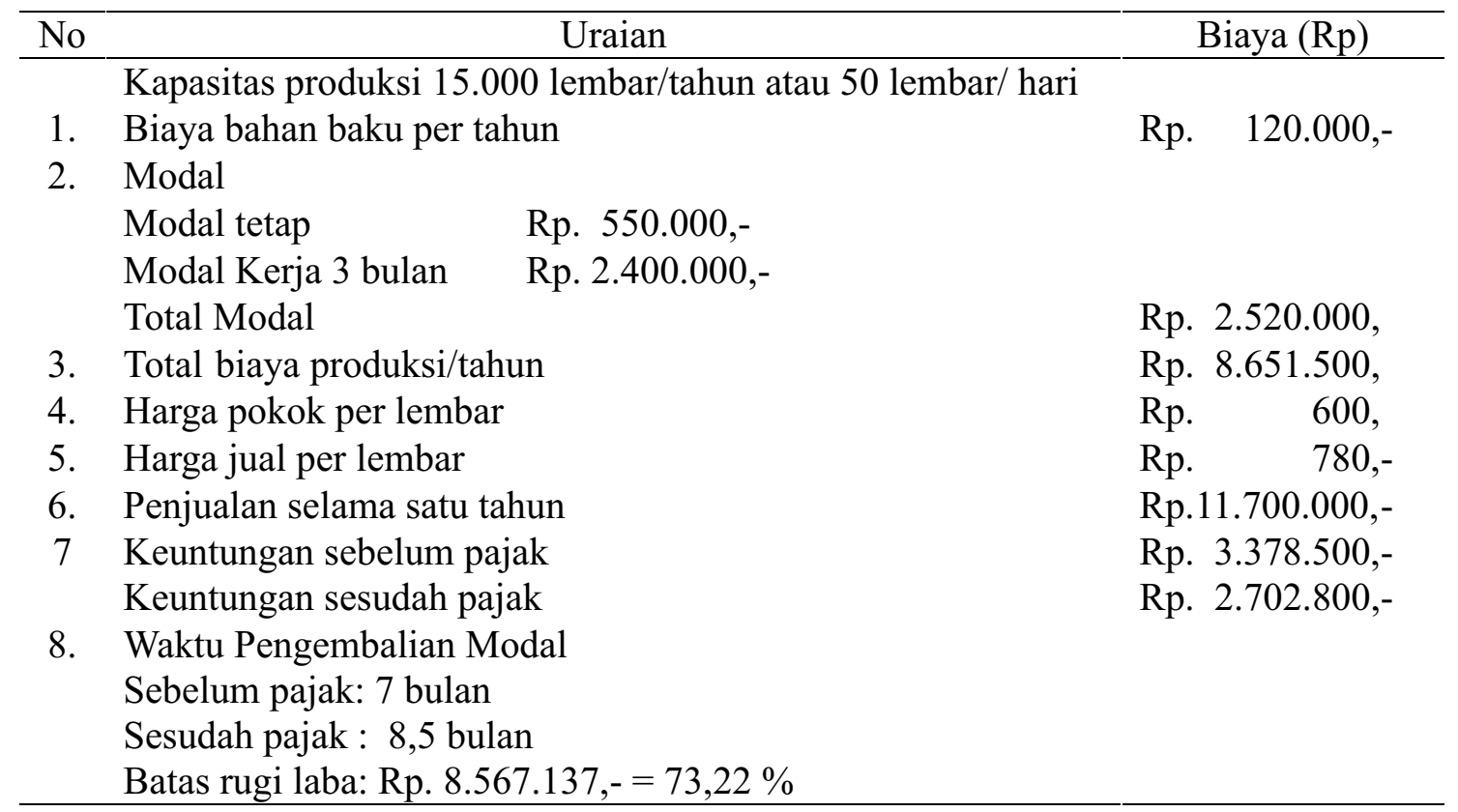

\section{KESIMPULAN}

1. Limbah shaving dapat di daur ulang menjadi kertas seni dengan menambahkan kertas bekas. Dengan demikian penelitian ini bisa mengatasi masalah pencemaran oleh limbah shaving dan menambah bahan baku kertas pada industri kertas.

2. Penggunaan lem fox sebagai perekat lebih baik dari pada lem pati.

3. Hasil uji kertas seni yang dipres lebih baik dari yang tidak di pres.

4. Indeks retak dan index tarik kertas seni hasil penelitian dengan menggunakan lem pati kanji masih dibawah kertas seni yang ada di pasaran, namun kertas seni yang menggunakan lem fox jauh lebih baik dari yang ada di pasaran.

5. Secara keseluruhan penampilan kertas seni hasil penelitian masih bisa bersaing dengan kertas seni yang ada di pasaran.

\section{UCAPAN TERIMAKASIH}

Pada kesempatan ini kami mengucapkan terimakasih kepada Bapak Sofyan Karani dan Ign Soenaryo yang sudah membimbing dan ikut serta melaksanakan penelitian ini sampai selesai dan berhasil. 


\section{DAFTAR PUSTAKA}

Abhinimpuno, Weko. 2007. Potensi Bahan Baku Alternatif untuk Kertas di Indonesia.(16 Maret 2011).

Anonim 2011, Environmental Paper Net work, Green Press Initiative.

Anonim, 2008, Technology of leather Manufacture, Developing countries training course on Eco-leather Manucture Technology, China Leather $\&$ Footwear Industry Research Institute. Aizz, 2011. Usaha Kertas Daur Ulang. Html.

Alamsyah, 2011, Kertas Daur Ulang, Dari Sampah Menjadi Rupiah, Jakarta Barat. http://www.artikelwirausaha.com/cate gory/database/tag/bardiju

Harun, W.K., Tugiana dan Sugeng, 2004. Pulp Kertas Seni dari Tanaman Serat bukan Kayu. Berita Sellulosa, Bandung, Vol. 39 No.1.

Marcot, Bruce, G., 2007. How Many Recycled Newspaper Does It Take to save A Tree?, The Ecology Plexus.

Ngatijo, Achmad Bunyamin, Maman Supratman, 1995. Pengamatan Mikroskopis Serat Daur Ulang, Berita Selulosa Tahun ke XXXI No 3.
Pasaribu, G., dan Sahwalito, 2006. Pengolahan Enceng Gondok sebagai Bahan baku Kertas Seni. Prosiding Ekspose Hasil-hasil Penelitian.

Sri Sutyasmi, 2009. Teknologi Pengambilan Kembali Krom dalam Limbah Shaving Industri Penyamakan Kulit, Jurnal Riset Industri, Vol III No.3 Desember 2009.

Sunaryo, Ign, Sri Sutyasmi, Widari dan Murwati , 2002. "Kulit Penggunaan Lemak Fleshing Industri Penyamakan Untuk Pembuatan Sabun Mandi". Majalah Kulit, Karet dan Plastik Volume II, Yogyakarta.

Tahirzadeh, Karimi, K., Keikhosro, 2008. Macrofibril and mikrofibril in the celulloce, J.Mol.Sci,9:1621 -1630.

Urip Santoso, 2009. Kertas Daur Ulang, J o u r n a 1 U i p s a n t o s o. http://uripsantoso,wordpress,com/2009 /05/17/asal-usul-kertas.

Zhiwen, D., 2008. Leather waste resuse technology. Developing Countries Trainning Course on Eco-Leather Manufacture Technology, Chinese Leather and Footwear Industry Research Institute. 